\title{
The Influence of Romanticism on Eugene O'Neill's Ecological Awareness
}

\author{
Guoping An \\ Foreign Language Institute of North China Electric Power University, Baoding, Hebei, China \\ No. 213 mail-box of Foreign Language Institute of North China Electric Power University, 071003 \\ Email:anguoping1015@yeah.net
}

\begin{abstract}
With the popularity of ecocriticism, Eugene O'Neill's ecological awareness has become a new target for many researchers. O'Neill inherited much nutrition from traditional Western philosophy, especially romanticism, which provides an access for O'Neill to observe nature and contemplate the relationship between man and nature. This paper tends to find out the influence of romanticism on O'Neill's ecological awareness.

Index Terms - romanticiam, Eugene O’Neill, ecological awareness, influence
\end{abstract}

\section{Introduction}

The theory of ecocriticism has provided a new perspective to research literature works. The European Romantic movement takes place in the late $18^{\text {th }}$ century. The Romantic Period in the history of American literature stretches from the end of the 18th century to the outbreak of the Civil War. During that period, the environment was severely damaged by industrial revolution. Against this background, many romanticists have created works to express their detestation towards industrial civilization and scientism, and curse about the industry and vulgar city life. They response Rousseau's call to return to nature and eulogize nature. Their thoughts are consistent with modern ecological ideas.

The first person who connects "ecology" with "romanticism" is Jonathan Bate, a famous ecocriticist in Liverpool University. He puts forward with the popular term "romantic ecology" in his book Romantic Ecology, Wordsworth and the Environmental Tradition. He combines romanticism with people's concern about the relationship between man and nature from the perspective of ecological thoughts. After that, the publication of Lawrence Buell's book The Environmental Imagination: Thoreau, Nature Writing, and the Formation of American Culture, has become a mile stone in American Environmental literature, which combines ecological literature sudy with romanticism.

Eugene O'Neill is the greatest American playwright. With tragedy his weapon, O'Neill spares no efforts to present spiritual dilemma that modern man suffers, to find out solutions for "the sickness of today", to understand his fellow being and discover basic truth, to find some balance between material wealth and one's mind and to make room for mind. O'Neill's works have shown strong awareness of ecology. With his sharp insight and intense sense of social responsibility, O'Neill contempltates seriously the ecological problems that human beings will have to face in the $20^{\text {th }}$ century. O'Neill's works have demonstrated strong ecological awareness. In term of the formation of O'Neill's ecological awareness, the playwright inherited much nutrition from traditional Western philosophy, especially romanticism with Rousseau and Thoreau as the representatives. This paper tends to find out the influence of romanticism on O'Neill's ecological awareness.

\section{Rousseau's Ecological Thoughts}

Jean Jacques Rousseau (1712-1778), the great SwissFrench thinker, philosopher,educator and writer, is an ideological pioneer, the most outstanding representative of enlightenment movement. His first major works, the Discourse on the Arts and Sciences (1750), argued that man is good by nature but has been corrupted by society and civilization; Rousseau's belief in the natural goodness of man set him apart from Roman Catholic writers who were hostile to the idea of progress. In the Discourse on the Origin and Foundations of Inequality Among Men (1754), he argued against Thomas Hobbes that human life before the formation of societies was healthy, happy and free and that vice arose as the result of social organization and especially the introduction of private property. Civil society, he held, comes into being only to ensure peace and to protect property, which not everyone has; it thus represents a fraudulent social contract that reinforces inequality. In the Social Contract (1762), which begins with the memorable line, "Man was born free, but he is everywhere in chains," Rousseau argues that a civil society based on a genuine social contract rather than a fraudulent one would provide people with a better kind of freedom in exchange for their natural independence, namely, political liberty, which he understands as obedience to a self-imposed law created by the "general will." His political philosophy influenced the French Revolution and the development of liberal, conservative and socialist theory.

From Rousseau's major woks, many experts regard him as the most important ecologisit in $18^{\text {th }}$ century. The emergence of Rousseau's ecological idea symbolizes the new stage of ecological thinking. Many ecological ideas and western philosophy can be traced back to Rousseau. His ecological thoughts include the following. Mankind should be far away from the societal burdens and live in intimacy with nature, for naure makes man free, kind and content while society makes man evil, enslaved and suffered. Rousseau admits that desire is a natural tendency for human,but what people pursue is likely to be excessive desire which drives 
people to be crazier about the material things. Rousseau clearly sees that the endless desire will swallow up the whole nature and human will get severe punishment. Moreover, Rousseau attacks on industrialized civilization and technology. He lists many projects that human feel proud of, but he doubts whether these achievements are a blessing or a curse to man since he has realized the damage of nature at his time. Besides, Rousseau pays close attention to man's inequality. He asserts that it is a violation of naure law that few people possess most of the material things while the majority suffer from poverty. Both Rousseau and Thoreau advocate the simple life. Worry and anxiety derive from greed and possession. Therefore, it is necessary for man to return to nature in order to pursue peaceful mind and spiritual world.

In his main writings, Rousseau identifies nature with the primitive state of savage man. Later he took nature to mean the spontaneity of the process by which man builds his egocentric, instinct based character and his little world. Nature thus signifies interiority and integrity, as opposed to that imprisonment and enslavement which society imposes in the name of progressive emancipation from cold-hearted brutality. Hence, to go back to nature means to restore to man the forces of this natural process, to place him outside every oppressing bond of society and the prejudices of civilization. It is this idea that made his thought particularly important in Romanticism.

Rousseau' influence can be found in O'Neill's portrayal of Simon Harford, a character in A Touch of the Poet. In order to defend his disgust of modern society, Simon dreams of a Utopian society and an idealistic government while advocating that man must strive hard in pursuit of freedom. Moreover, Simon launches an attack on private property and man's greed, claiming the virtue of living in simplicity. Simon holds that the private property will tempt men's greed into slaving one another, so man must be immune to his stupid possessive instincs and outgrow them spiritually. Besides, the spiritual fulfillment is stressed instead of material pursuit.

\section{Thoreau's Ecological Thoughts}

Rousseau did exert some influence on several later Transcendentalists such as philosopher Henry David Thoreau(1817-1862). He was an American author, naturalist, transcendentalist, tax resister, development critic, philosopher, and abolitionist who is best known for Walden, a reflection upon simple living in natural surroundings, and his essay, Civil Disobedience, an argument for individual resistance to civil government in moral opposition to an unjust state. Thoreau's books, articles, essays, journals and poetry total over 20 volumes. Among his lasting contributions were his writings on natural history and philosophy, where he anticipated the methods and findings of ecology and environmental history, two sources of contemporary environmentalism.

As a frontier ecologist of American romanticism, Thoreau argues that simplicity in material things is practical and beneficial for mankind. In his view, the development of humanity is not just the possession of more and more material wealth, but rather the enrichment of man's spiritual fufillment as well as the promotion of man's morality. Meanwhile, only by living in harmony with nature will man live in harmony with himself, which is the ultimate pursuit of mankind. Throeau calls on and practices in person in life in simplicity which aims at the maximal enrichment of man's spiritual life with the exchange of a living as simple as possible. Thoreau chose to live alone in his cabin on Walden Pond for two year, where he accomplished his masterpiece Walden. In a modern sense, to live in simplicity is to simplify man's material life as far as possible, so that man will have time to communicate with nature as much as possible, and thus heighten man's spiritual pursuit and aesthetic taste.

Just as an ecocriticist David Mazel commented in his book A Century of Early Ecocriticism: "Thoreau's experiment actually presuppposed all that complicated civilization which it theoretically abjured. His aim was a noble and a useful one, in the direction of plain living and high thinking....his whole life was a rebuke of the waste and aimlessness of our American luxury, which is an abject enslavement to tawdry upholstery. His better style as a writer is in keeping with simplicity and purity of his life."Although Thoreau's doctrines were not accepted by his generation, his lifestyle has had a pervasive influence as an example of moral heroism that inspires man to search continuously for a spiritual dimension in American life. His greatness stems from his principal ideas of nature and ecology which call for all men the freedom of living and making living itself an art. The most influential perspective of Thoreau is the harmonious appreciation of man's coexistence with nature.

Imitating Thoreau, O’Neill has once lived "a Thoreaulike existence in utter isolation in a remodeled Coast Guard Station on Cape Cod amidst trackless sand dunes that were bounded on the east, west, and south by'land unknown'and on the north by the Atlantic Ocean. "Just as John H. Raleigh commented in his works The Plays of Eugene O'Neill : "For great periods of his life, no matter where he happened to be living at the same time, he was the twentieth-century Thoreau, almost completely isolated from normal human society."The playwright is extraordinary influenced by Thoreau when woking on A Touch of the Poet. He even buys three books written by Thoreau.

\section{O'Neill's Inheritance from Romanticism}

Following the trend of romanticists, especially Thoreau and Rousseau, O'Neill creates his works, A Touch of the Poet and More Stately Mansions. These two plays are filled with touches of romanticism. The main character Simon wants to prove his independence and practice a self-suffient way of living, so he builds his own cabin, laboring to support himself as Thoreau does. Living in nature, Simon feels his integration with nature, and nature has inspired his contemplations about what life means. What's more, he intends to conceive a book about how the world is changed. In such a society, people will neither be so greedy to possess money and land nor will they take advantage of each other. People will be content with few material things and live in peace and freedom as if they were 
in heaven. Only through the ecological practice of living in simplicity can man achieve his self-realization. Less desire can contribute to setting a higher goal.

Later in More Stately Mansions, though Simon has gradually turned into a businessman, he still holds on his dream of building a fair society characteristic of no oppression. Here, O'Neill clearly states that returning nature is the innate call of human nature and liberty from man's dilemma. Influenced by romanticism, O'Neill maintians that human nature is good and unselfish in essence, but man has been degraded by materialized society. The outlet for mankind is to return to nature and simplicity. Besides, only by the dispossession of the chains of material will man regain his dignity and humanity, just as the ending of More Stately Mansions indicates. Sara abandons the stately mansion which represents wealth and fame. She brings Simon to the farm to get well. Living on the farm, Sara will labor in the field with her bare feet in the earth.Such a simple and ordinary life can give her sense of happiness and tranquility. Nora, Sara's daughter, also begins to know the real meaning of love and life. She will follow her mother's step to labor and live in dignity and peace.

The portrayal of Sara's spiritual growth and ultimate return to nature and simplicity signifies O'Neill's heritage of romanticism. Man can ge rewarded by his spiritual renewal in harmony with nature. Pursuing money and fame all day will lead to the loss of man's sense of belongings. Content is happiness, so man should learn to abandon worldly things in order to get rebirth and transform himself. Only in this way, can man be united with nature and his inner self.

\section{Conclusion}

Both being a Nobel Prize winner and a foremost American playwright, O'Neill hold serious attitude towards his works.
He never serves for greed or disgrace. He strives by all means to find out the meaning of his life. The traditional adoration of nature deeply roots in O'Neill's heart and life style. In his drama, many characters go back to live in the bossom of nature and to be near nature, such as Anna Christie, Simon Harford, Robert Mayo and so on. In O'Neill's exploration, it is a wise behavior for man's abandonment of the influence of materialism and consumption culture. Returning to nature is a progess in human history because it is a new start for man to regain the lost humanity and harmony. Only by living in intimacy with nature and living in simplicity will man achieve self-fulfillment and man-nature harmony.

\section{Acknowledgment}

This research is financially supported by the Fundamental Research Funds for the Central Universities (Grant NO. 2014MS181).

\section{References}

[1] Mazel, David, ed. A Century of Early Ecocriticism. Athens: University of Georgia Press, 2001.

[2] O'Neill, Eugene. Anthology of American Literature. $3^{\text {rd }}$.ed.vol.2.part2. New York: Macmillan Publishing Company, 1985.

[3] Shengzhen zhang, A Study of Eugene O'Neill's Ecological Awareness in His Plays, Doctor Thesis of Shandong University, 2009.

[4] West, Rinda, Out of the Shadow: Ecopsychology, Story, and Encounter with the Land. Charlottesville and London: University of Virginia Press, 2007.

[5] Westling, Louise H. The Green Breasts of the New World: Landscape, Gender, and American Fiction. Athens: University of Georgia Press, 1996.

[6] Weston, Anthony. An Invitation to Environmental Philosophy. New York: Oxford University Press, 1999. 